\title{
Serum Alkaline Phosphatase and Rickets in Urban Schoolchildren
}

\author{
W. T. COOKE, C. H. J. SWAN, P. ASQUITH, V. MELIKIAN, W. E. MCFEELY
}

British Medical fournal, 1973, 1, 324-327

\section{Summary}

Among 569 schoolchildren (386 boys and 183 girls) aged 14-17 years, 233 had serum alkaline phosphatase values of 30 K.A. units or greater. There was no significant difference in the results in Asian, white, or West Indian children. The mean values were significantly greater in boys than girls and both showed a fall in mean values with increasing age. Radiological rickets occurred in at least $4 \%$ of the survey, and was more common in Asians. Low calcium and high hydroxyproline excretion in most of those investigated and the response to vitamin $D$ therapy suggests that most children with alkaline phosphatase levels above 30 K.A. units have rickets.

Since the decline of the widespread supplementation of the diet with vitamin $D$, the demands of the physiological growth spurt for extra vitamin $D$ in adolescents already on a borderline intake may be responsible for the great increase in "biochemical" rickets. Once the growth spurt is over the condition subsides but the results of impaired growth or permanent pelvic deformity will not necessarily be eradicated.

\section{Introduction}

Previous reports on osteomalacia or rickets occurring in immigrants have emphasized the almost exclusive affliction of Asians (Dunnigan et al., 1962; Benson et al., 1963; Ford et al., 1972a). Since an earlier report (Swan and Cooke, 1971) giving findings in 25 Asians seen in Birmingham, a further 45 patients with osteomalacia or rickets have been referred to the nutritional and intestinal unit. Of these 70 patients 34 were aged 11 to 19 years and all except three were attending Birmingham schools, with two being West Indian, two white, and the remainder Asian. This predominance of Asians suggested the need for a survey covering Asians, white, and West Indian children to establish whether in an unselected population there was any significant difference between the races in regard to levels of serum alkaline phosphatase or the incidence of rickets. In addition, the occurrence of asymptomatic but radiologically severe rickets in children of one of the present patients (fig. 1) made such a survey essential.

\section{Methods}

The head teachers of five comprehensive schools were approached for the names and addresses of their pupils in the age range 14

\section{United Birmingham Hospitals, The General Hospital, Birmingham B4 6NH \\ W. T. COOKE, M.D., F.R.C.P., Consultant Physician}

W. E. MCFEELY, M.B., D.M.R.D., Senior Radiological Registrar

North Stafiordshire Royal Infirmary, Stoke-on-Trent

C. H. J. SWAN, M.D., M.R.C.P., Consultant Physician

Department of Experimental Pathology, Birmingham University, Birmingham B15 2TH

P. ASQUITH, M.D., M.R.C.P., Clinical Senior Lecturer

Dudley Road Hospital, Birmingham 18

V. MELIKIAN, M.B., M.R.C.P., Consultant Physician

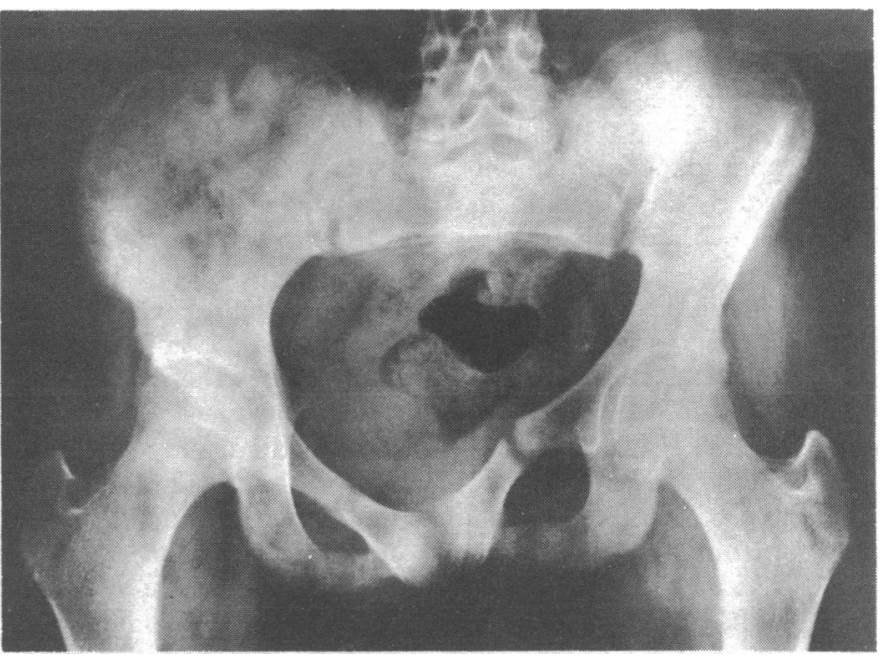

FIG. 1-Radiograph showing severe rickets in an asymptomatic 17-year-old Asian schoolgirl (serum alkaline phosphatase $43 \mathrm{~K}$.A. units). Her twin sister, also asymptomatic (serum alkaline phosphatase $53 \mathrm{~K}$.A. units), had similar findings but without displacement of pubic ramus.

to 17 years. The purpose of the proposed investigation was explained by letter to the parents and their permission sought to take blood samples from their children. This was given by about half of those approached and this proportion did not vary between the schools. The schools were visited by a team of doctors, nurses, and medical students. Pupils who had parental permission were checked for birth date, weighed and measured without shoes, and $25 \mathrm{ml}$ of blood was withdrawn without the use of a tourniquet. In all, 569 schoolchildren were examined consisting of 227 Asian, 185 whites, and 157 West Indians. The blood was separated into three aliquots, for haematological (haemoglobin, red and white cell counts) and biochemical (calcium, alkaline phosphatase, albumin, globulin, bilirubin, glutamic oxaloacetic transaminase, iron, sodium, potassium, and urea) assessment, and for serum vitamin $\mathbf{B}_{12}$ and folic acid measurement.

Children with serum alkaline phosphatase levels of 30 K.A. units or greater were asked to attend hospital with their parents. At this second visit the blood examination was repeated, together with determination of serum 5-nucleotidase levels in most. The parents and children were interviewed for symptoms, diet, previous illness, and country of origin. Radiographs of the chest, wrist, knee, and pelvis were taken. Also, each child, while remaining on his usual diet, collected his urine for 24 hours which was analysed for calcium, creatinine, and total hydroxyproline. The children were then given calciferol $1.25 \mathrm{mg}$ daily, and seen monthly for rechecking of height, weight, and laboratory findings. The unexpected size of the problem compelled the follow-up to be limited. Thus, only 133 (53\% of those with alkaline phosphatase more than 30 K.A. units) were treated, being those that were seen earliest in the survey. Those seen later were not followed-up or treated.

Haematological examinations were carried out by the haematology laboratory (Dr. Andrew Pollock) using a Coulter counter (model S). Bloods were also checked for other abnormalities including leucopenia, sickling glucose-6-phosphate dehydrogenase deficiency, and other abnormal haemoglobins. The biochemical estimations were performed in the biochemical laboratory (Dr. Barry Northam) using autoanalyser methods 
(Roberts, 1966). Alkaline phosphatase was determined by a modified Kind and King (1954) method on the autoanalyser in which the substrate was $7.0 \mathrm{mM}$ instead of $4.8 \mathrm{mM}$ and the bicarbonate-carbonate buffer was supplemented by the addition of $1 \mathrm{mmol} / 1 . \mathrm{Mg}^{++}$ions. The normal range for adults in this laboratory is 5-14 K.A. units. During the period of this investigation the laboratory participated in a national quality control system and had a slight positive bias of 1.3 K.A. units, which was not statistically significant. In the higher ranges, 16 randomly selected sera from the children in this survey (range 21-60 K.A. units, mean 41) assayed without addition of magnesium gave a mean decrease of $19 \%$ compared with those assayed with added magnesium. Total hydroxyproline was determined by amino-acid autoanalyser by Dr. Roy Jeffries in the Department of Experimental Pathology, Birmingham University.

\section{Results}

Serum levels of alkaline phosphatase, calcium, and albumin, and also height and weight with regard to age, sex, and race are given in the table and fig. 2 shows the distribution of serum alkaline phosphatase with regard to race and sex. There was no significant difference between the levels of alkaline phosphatase in the three races in either the boys or the girls. There was, however, a significant difference between those found in boys and girls in the different age groups (see table). If the serum values of healthy children could be assumed to have a normal gaussian distribution, then using the method of Hoffman (1963) the $95 \%$ confidence limits for normality in girls was clear cut, being 8-17 K.A. units and that for boys in this age range 9-23.

Other Laboratory Findings.-Altogether, $4.4 \%$ had serum calcium values less than $9.0 \mathrm{mg} / 100 \mathrm{ml}$ in boys or $8.7 \mathrm{mg} / 100 \mathrm{ml}$ in girls. There were 20 Asian boys, four Asian girls, and one white boy. Serum albumin levels were $4.4 \mathrm{~g} / 100 \mathrm{ml}$ or more in all with low serum calcium levels. Haemoglobin values of less than $13.0 \mathrm{~g} / 100 \mathrm{ml}$ in boys was found in $15.5 \%$ Asians, $7.7 \%$ whites, and $25 \%$ West Indians. In the girls, values less than $12.5 \mathrm{~g} / 100 \mathrm{ml}$ were present in $36 \%$ Asians, $9 \%$ whites, and $36 \%$ West Indians. Serum iron values less than $60 \mu \mathrm{g}$ were found in $14.6 \%$ of the children. Among the boys deficiency was present in $17.8 \%$ Asians, $9 \%$ whites, and $4 \%$ West Indians, while in the

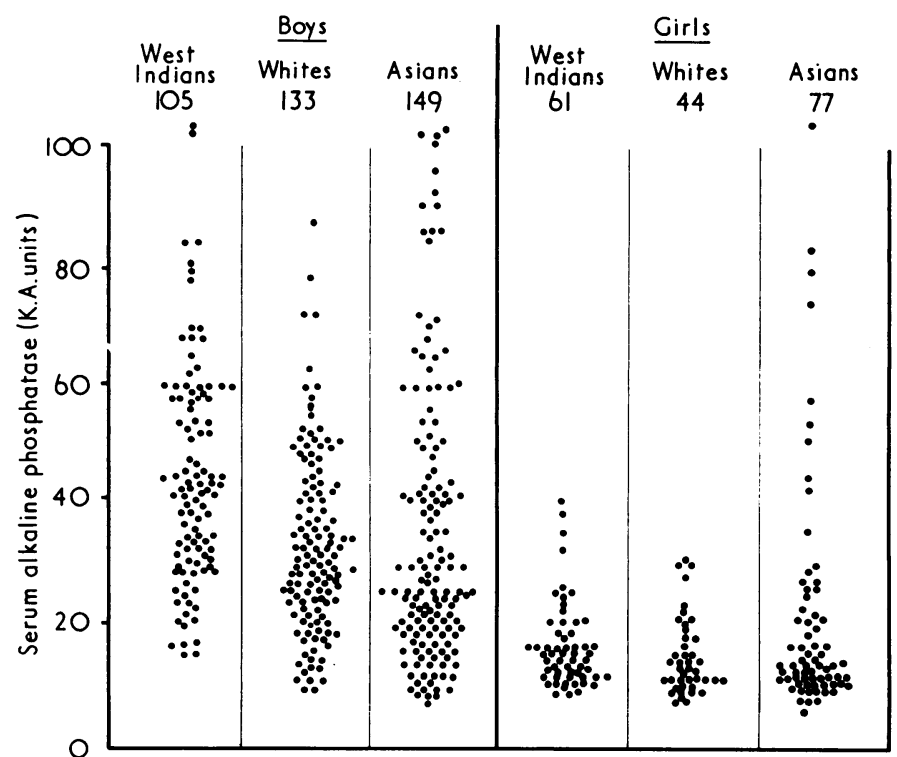

FIG. 2-Distribution of serum alkaline phosphatase levels in boys and in girls according to their age.

girls the figures were $26 \%$ Asians, $27 \%$ whites, and $8 \%$ West Indians. Low serum folic acid levels (lactobacillus Casei), less than $3 \mathrm{pg} / \mathrm{ml}$, were present in $12.2 \%$ of all the boys, while $20 \%$ of the West Indian boys had low serum folate values compared with about $9 \%$ Asians and $10 \%$ whites. On the other hand, only $8.6 \%$ Asian, $9 \%$ white, and $10 \%$ of the West Indian girls had low values. A low serum $B_{12}$ (less than $150 \mu \mathrm{g} / \mathrm{ml}$ ) was seen in 12 children, eight Asian, two whites, and two West Indians. None of these deficiencies showed a significant relation to a raised serum alkaline phosphatase. A full report on the haematological findings will be published later.

Urinary Excretion.-Urines were collected by 123 children. The findings in 113 boys are shown in fig. 3 with 60 excreting less than $50 \mathrm{mg}$ calcium per 24 hours. There was no significant relation between urinary calcium and serum alkaline phosphatase. Total hydroxyproline excretion was determined in 80 boys and the findings are shown in fig. 4. There was no significant correlation with either the serum alkaline phosphatase or the urinary calcium excretion.

Various Mean Serum Levels, Height, and Weight together with Age, Sex, and Race in the Patients Studied

\begin{tabular}{|c|c|c|c|c|c|c|c|c|c|c|c|c|}
\hline & \multirow{2}{*}{$\begin{array}{l}\text { No. } \\
\text { of } \\
\text { Cases }\end{array}$} & \multicolumn{3}{|c|}{$\begin{array}{l}\text { Serum Alkaline Phosphatase } \\
\text { (K.A. Units) }\end{array}$} & \multicolumn{2}{|c|}{$\underset{(\mathrm{mg} / 100 \mathrm{ml})}{\text { Serum }}$} & \multicolumn{2}{|c|}{$\underset{(\mathrm{g} / 100 \mathrm{ml})}{\operatorname{Serum} \text { Albumin }}$} & \multicolumn{2}{|c|}{$\underset{(\mathrm{cm})}{\text { Height }}$} & \multicolumn{2}{|c|}{$\underset{(\mathbf{k g})}{\text { Weight }}$} \\
\hline & & Mean & S.D. & $\begin{array}{l}\text { Difference } \\
\text { Boys/Girls } \\
\qquad\end{array}$ & Mean & S.D. & Mean & S.D. & Mean & S.D. & Mean & S.D. \\
\hline \multicolumn{13}{|c|}{ Girls } \\
\hline All races Age 14: & 44 & $20 \cdot 6$ & $7 \cdot 6$ & $<0.001$ & & & & & & & & \\
\hline 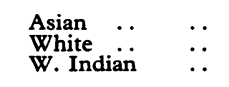 & $\begin{array}{l}15 \\
14 \\
15\end{array}$ & $\begin{array}{l}22 \cdot 0 \\
21 \cdot 0 \\
19 \cdot 0\end{array}$ & $\begin{array}{l}9 \cdot 1 \\
7 \cdot 9 \\
5 \cdot 6\end{array}$ & $\begin{array}{l}<0.005 \\
<0.001 \\
<0.001\end{array}$ & $\begin{array}{l}10 \cdot 0 \\
10 \cdot 3 \\
10 \cdot 3\end{array}$ & $\begin{array}{l}0.38 \\
0.37 \\
0.30\end{array}$ & $\begin{array}{l}4 \cdot 77 \\
4 \cdot 87 \\
4 \cdot 84\end{array}$ & $\begin{array}{l}0.31 \\
0.31 \\
0.34\end{array}$ & $\begin{array}{l}155 \cdot 4 \\
156.7 \\
158.9\end{array}$ & $\begin{array}{l}4 \cdot 8 \\
5 \cdot 6 \\
5 \cdot 7\end{array}$ & $\begin{array}{l}43.9 \\
53.5 \\
57 \cdot 6\end{array}$ & $\begin{array}{r}5 \cdot 7 \\
10 \cdot 4 \\
10 \cdot 4\end{array}$ \\
\hline 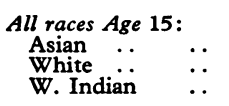 & $\begin{array}{l}84 \\
35 \\
24 \\
25\end{array}$ & $\begin{array}{l}19 \cdot 3 \\
24 \cdot 8 \\
16 \cdot 9 \\
13 \cdot 8\end{array}$ & $\begin{array}{r}19.9 \\
28 \cdot 5 \\
10 \cdot 7 \\
4 \cdot 8\end{array}$ & $\begin{array}{l}<0.001 \\
<0.05 \\
<0.001 \\
<0.001\end{array}$ & $\begin{array}{r}9 \cdot 7 \\
10 \cdot 1 \\
9 \cdot 7\end{array}$ & $\begin{array}{l}0.58 \\
0.34 \\
0.38\end{array}$ & $\begin{array}{l}4 \cdot 91 \\
4 \cdot 83 \\
4.63\end{array}$ & $\begin{array}{l}0.23 \\
0.36 \\
0.21\end{array}$ & $\begin{array}{l}155 \cdot 2 \\
156 \cdot 7 \\
159 \cdot 4\end{array}$ & $\begin{array}{l}6 \cdot 6 \\
6 \cdot 0 \\
4 \cdot 5\end{array}$ & $\begin{array}{l}46 \cdot 0 \\
50 \cdot 0 \\
53 \cdot 9\end{array}$ & $\begin{array}{l}6 \cdot 2 \\
5 \cdot 9 \\
7 \cdot 7\end{array}$ \\
\hline 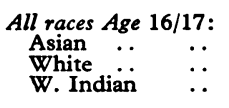 & $\begin{array}{r}55 \\
29 \\
17 \\
9\end{array}$ & $\begin{array}{l}13 \cdot 0 \\
14 \cdot 9 \\
10 \cdot 0 \\
12 \cdot 6\end{array}$ & $\begin{array}{r}9 \cdot 6 \\
12 \cdot 7 \\
2 \cdot 8 \\
2 \cdot 3\end{array}$ & $\begin{array}{l}<0.001 \\
<0.02 \\
<0.001 \\
<0.01\end{array}$ & $\begin{array}{r}9 \cdot 8 \\
10 \cdot 1 \\
9 \cdot 9\end{array}$ & $\begin{array}{l}0.67 \\
0.44 \\
0.23\end{array}$ & $\begin{array}{l}4 \cdot 90 \\
4 \cdot 89 \\
4 \cdot 90\end{array}$ & $\begin{array}{l}0 \cdot 17 \\
0.30 \\
0 \cdot 23\end{array}$ & $\begin{array}{l}153.9 \\
161.9 \\
158.9\end{array}$ & $\begin{array}{l}5 \cdot 2 \\
6 \cdot 8 \\
4 \cdot 9\end{array}$ & $\begin{array}{l}45 \cdot 9 \\
58 \cdot 8 \\
54 \cdot 7\end{array}$ & $\begin{array}{r}6.8 \\
11.5 \\
10.5\end{array}$ \\
\hline \multicolumn{13}{|c|}{ Boys } \\
\hline $\begin{array}{cc}\text { All races } & \text { Age } 14: \\
\text { Asian } & . . \\
\text { White } & \ldots \\
\text { W. Indian } & \ldots\end{array}$ & $\begin{array}{r}146 \\
57 \\
40 \\
49\end{array}$ & $\begin{array}{l}44 \cdot 7 \\
42 \cdot 7 \\
41 \cdot 8 \\
49 \cdot 1\end{array}$ & $\begin{array}{l}19 \cdot 2 \\
23 \cdot 4 \\
16 \cdot 3 \\
15 \cdot 1\end{array}$ & $\begin{array}{l}<0.001 \\
<0.005 \\
<0.001 \\
<0.001\end{array}$ & $\begin{array}{l}9 \cdot 5 \\
9 \cdot 9 \\
9 \cdot 8\end{array}$ & $\begin{array}{l}0 \cdot 70 \\
0 \cdot 30 \\
0 \cdot 29\end{array}$ & $\begin{array}{l}4 \cdot 86 \\
4 \cdot 84 \\
4 \cdot 73\end{array}$ & $\begin{array}{l}0.32 \\
0 \cdot 24 \\
0.24\end{array}$ & $\begin{array}{l}160 \cdot 4 \\
163 \cdot 7 \\
163.9\end{array}$ & $\begin{array}{l}7 \cdot 7 \\
7 \cdot 7 \\
7 \cdot 9\end{array}$ & $\begin{array}{l}47 \cdot 4 \\
55 \cdot 4 \\
53 \cdot 9\end{array}$ & $\begin{array}{r}10 \cdot 0 \\
11 \cdot 1 \\
8.7\end{array}$ \\
\hline 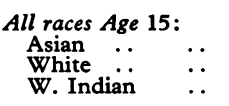 & $\begin{array}{r}154 \\
47 \\
64 \\
43\end{array}$ & $\begin{array}{l}39 \cdot 6 \\
37 \cdot 7 \\
34 \cdot 2 \\
48 \cdot 4\end{array}$ & $\begin{array}{l}19 \cdot 4 \\
22 \cdot 9 \\
11 \cdot 3 \\
21 \cdot 4\end{array}$ & $\begin{array}{l}<0.001 \\
<0.05 \\
<0.001 \\
<0.001\end{array}$ & $\begin{array}{r}9 \cdot 7 \\
10 \cdot 1 \\
9.9\end{array}$ & $\begin{array}{l}0.70 \\
0.35 \\
0.34\end{array}$ & $\begin{array}{l}4.80 \\
4.92 \\
4 \cdot 71\end{array}$ & $\begin{array}{l}0.29 \\
0.28 \\
0.39\end{array}$ & $\begin{array}{l}164 \cdot 1 \\
164 \cdot 7 \\
166 \cdot 7\end{array}$ & $\begin{array}{l}7 \cdot 6 \\
7 \cdot 1 \\
7 \cdot 1\end{array}$ & $\begin{array}{l}53 \cdot 2 \\
55 \cdot 0 \\
55 \cdot 2\end{array}$ & $\begin{array}{r}10 \cdot 2 \\
8 \cdot 0 \\
8 \cdot 5\end{array}$ \\
\hline 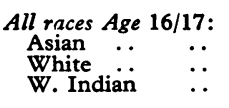 & $\begin{array}{l}86 \\
44 \\
26 \\
16\end{array}$ & $\begin{array}{l}26 \cdot 6 \\
26 \cdot 1 \\
23 \cdot 5 \\
32 \cdot 6\end{array}$ & $\begin{array}{l}19 \cdot 0 \\
21 \cdot 0 \\
14 \cdot 6 \\
19 \cdot 5\end{array}$ & $\begin{array}{l}<0.001 \\
<0.02 \\
<0.001 \\
<0.01\end{array}$ & $\begin{array}{r}9.6 \\
10 \cdot 0 \\
9 \cdot 9\end{array}$ & $\begin{array}{l}0.86 \\
0.33 \\
0.34\end{array}$ & $\begin{array}{l}4.94 \\
4.93 \\
4.82\end{array}$ & $\begin{array}{l}0.26 \\
0.25 \\
0.28\end{array}$ & $\begin{array}{l}166.6 \\
170 \cdot 9 \\
171 \cdot 0\end{array}$ & $\begin{array}{l}7 \cdot 1 \\
8 \cdot 3 \\
6 \cdot 7\end{array}$ & $\begin{array}{l}55.1 \\
62.5 \\
62.8\end{array}$ & $\begin{array}{r}6.7 \\
10.5 \\
9.6\end{array}$ \\
\hline
\end{tabular}




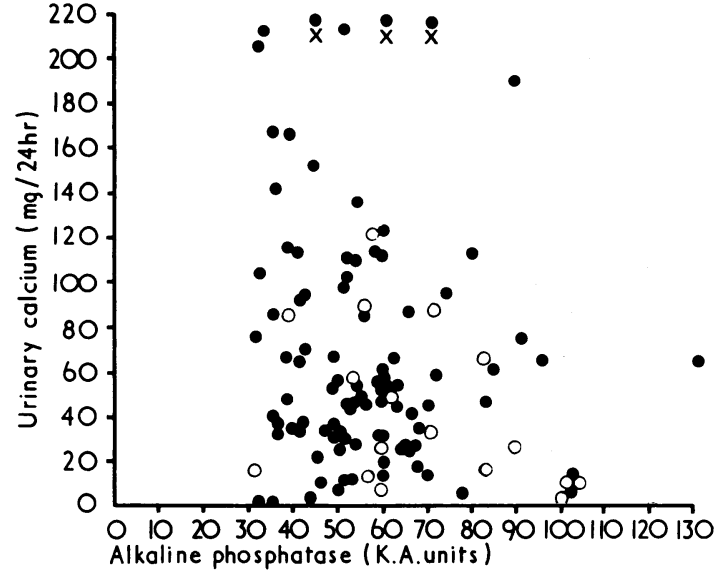

FIG. 3-Urinary excretion of calcium per 24 hours in 113 boys is plotted against the alkaline phosphatase levels. $\mathrm{O}=$ Radiological evidence of rickets.

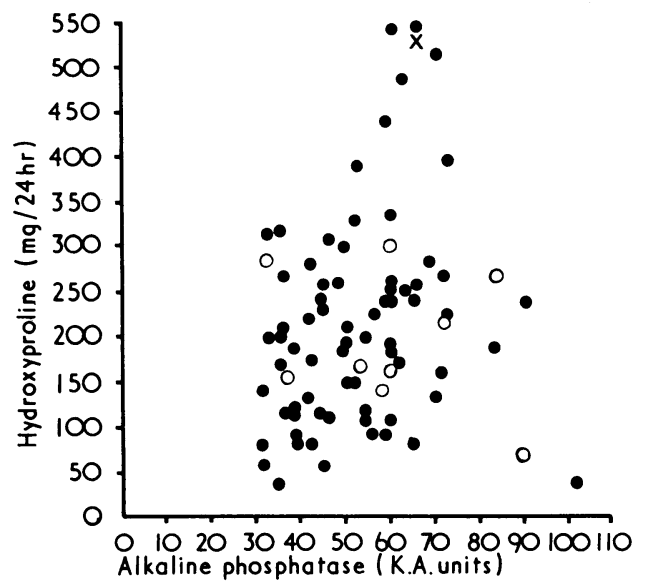

FIG. 4-Urinary excretion of total hydroxyproline per 24 hours in 80 boys is plotted against the alkaline phosphatase levels. $\mathrm{O}=$ Radiological evidence of riclets.

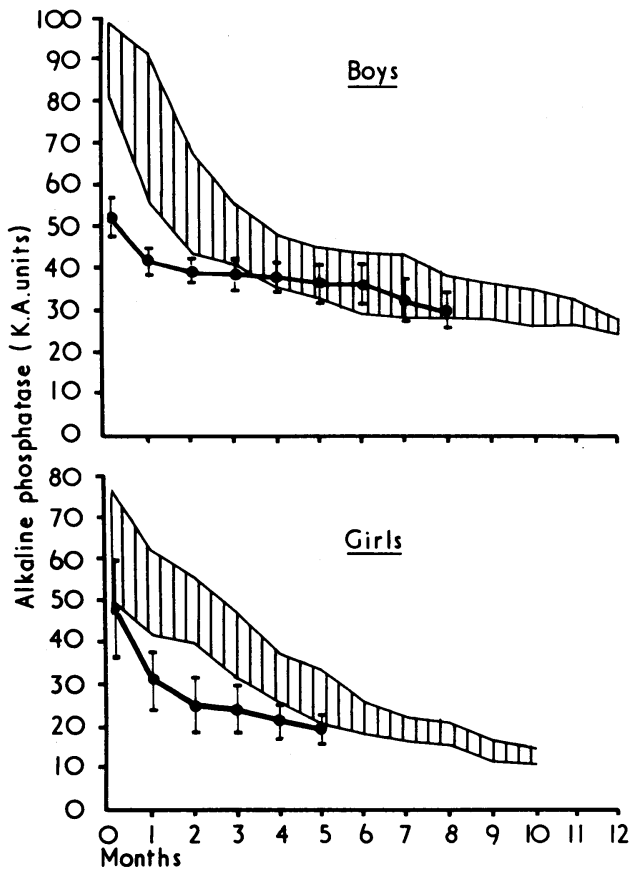

FIG. 5-Fall (mean \pm 2 S.E.) $n$ serum alkaline phosphatase after treatment with $1.25 \mathrm{mg}$ calciferol daily of 46 boys and six girls, compared with the response (mean \pm 2 S.E.) found in 20 boys and 10 girls with proved rickets.
Radiological Findings.-Radiographs were taken of 133 chidren. For the purpose of diagnosing rickets, only changes found in wrists and knees were considered. Protrusio acetabuli, opacification of the pelvis (Steinbach and Kolb, 1964; Fourman et al., 1968), or changes in trabecular pattern were not used as primary evidence of rickets. Of the 17 boys with radiological evidence of rickets 12 were Asians and five were West Indians; none were white. Seven of the 15 girls investigated had radiological rickets and all were Asian. The lack of correlation between radiological rickets and the serum alkaline phosphatase, urinary excretion of calcium, and of hydroxyproline is shown in figs. 3 and 4.

Response to Calciferol.-Of the 133 pupils from the school survey started on treatment 46 boys and six girls had been followed for at least five months at the time of writing. Their response to therapy as reflected by levels of serum alkaline phosphatase is shown in fig. 5 , and compared with the response obtained with a similar dosage of calciferol in 20 boys and 10 girls of the total of 70 who presented separately with proved rickets (based on bone biopsy and/or Looser's zones and raised alkaline phosphatase). Non-specific symptoms of lassitude, muscle weakness, aches, and pains as described by other workers (Prineas et al., 1965; Thomas, 1967; Ford et al., 1972b) were relieved by therapy, often in a sufficiently striking manner to be commented on by their teachers. A full report on the results of therapy will be presented when the follow-up study is completed.

\section{Discussion}

Serum alkaline phosphatase is well recognized as a screening method for the presence of osteomalacia or rickets. In adults, the range of normal values are well established but evidence on the normal range to be expected in adolescent children is scarce. Sereny and McLaughlin (1970) could find only one reference work in which it was suggested that the upper normal limit was 20-25 K.A. units. They studied 55 healthy boys aged 12-16 and found a range between 5 and $47 \mathrm{~K}$.A. units with a mean of 20 and $95 \%$ confidence limit between 5 and 35 units. Belfield and Goldberg (1971) in 17 patients aged 11-16 gave their upper limit as 22.3 K.A. units. Round (1972) in a survey of an unstated total number of London schoolchildren, but which included 201 boys and 160 girls between the ages of 12-15, found the mean levels in 13-year-old boys to be about $20 \mathrm{~K}$.A. units, falling in successive age groups to approach normal adult ranges at age 17 , while the maximum mean in girls was about $18 \mathrm{~K}$.A. units at the age of 12 and approached normal adult values at the age of 14 . A few high values were noted; $30-38 \mathrm{~K}$.A. units in the boys and $28 \mathrm{~K}$.A. units in the girls.

Statistical analysis of our findings suggest that the upper limit for boys aged $14-17$ is 23 K.A. units and girls 17 K.A. units, values similar to those noted by other workers. A distinct fall in mean values is also shown in the three age groups studied, although the normal adult range was not reached in either boys or girls contrary to Round's (1972) observation. Extrapolation of the mean values of serum alkaline phosphatase suggests that normal adult values will be reached by the age of 20 . This relation to age seems likely to be connected with the physiological growth spurt well documented by Tanner et al. (1966). It seems important, however, that before the raised alkaline phosphatase values that we or other authors have found can be entirely attributable to the physiological growth spurt other criteria pertinent to skeletal normality should be checked. For this reason the radiological features, therapeutic response to vitamin $\mathrm{D}$, and the urinary excretion of both hydroxyproline and calcium were examined.

Hydroxyproline reflects turnover of skeletal collagen and is closely related to growth rate (Tanner et al., 1966). Increased excretion is usually but not invariably present in osteomalacia 
(Smith and Dick, 1968); Zorab (1969) found the upper limit of excretion in 14-year-old boys on a gelatin-free diet to be 206 $\mathrm{mg} / 24 \mathrm{hr}$, while $150 \mathrm{mg}$ was the upper limit noted by Jasin et al. (1962). The fact that the diet in this survey was not meat-free or gelatin-free will increase the values. Even so, $30 \%$ of the schoolchildren had abnormally high values, greater than $250 \mathrm{mg}$, and only $30 \%$ had less than $150 \mathrm{mg}$ a day. In some children calcium was virtually undetectable in the urine and was less than $50 \mathrm{mg} / 24 \mathrm{hr}$ in $53 \%$ of those examined.

Radiological investigation showed that $24(18 \%)$ of the 133 children investigated-that is, a minimum incidence of $4.2 \%$ of the original 569 children-had rickets. In this group of 133 schoolchildren, who all had raised alkaline phosphatase levels, there was no statistical correlation between the presence of radiological rickets and the increased hydroxyproline excretion, low urinary calcium, or the levels of alkaline phosphatase. Nevertheless, the conclusion that most if not all of these children with serum alkaline phosphatase levels above $30 \mathrm{~K}$.A. units might have rickets seems justified.

This suggestion is supported by the response to vitamin D therapy. This was variable, with some children, especially the girls, showing striking response and others taking up to six months of treatment before there was a consistent and progressive fall. Even so, the mean values at the end of six months of the 46 boys who had been followed up so far were essentially the same as those seen in 20 proved rachitic patients not in the school survey who were similarly treated (fig. 5). The disappearance of clinical symptoms, the existence of which was not always appreciated before therapy, and the effect on growth rates was particularly noticeable. We have not been able to uncover other causes for the high alkaline phosphatase, for the normal 5-nucleotidase values make hepatic disease unlikely and only isoenzymes of bone were detected in those sera examined.

In considering the aetiological factors, our results show no significant difference in serum levels of alkaline phosphatase among Asian, white, and West Indian children. It is of interest, however, that children with radiological rickets were mainly Asian. The similar incidence of biochemical rickets in the three racial groups studied suggest that factors such as skin pigmentation (Loomis, 1967) and dietary phytate (Ford et al., 1972b; Wills et al., 1972) are not the whole explanation. An alternative hypothesis that the aetiology is different in each race seems improbable. There is a significant difference in each age group studied between the levels of alkaline phosphatase in boys and those of girls. This difference seems unlikely to be due to the later puberty in boys as there is still a significant difference between the older boys and the younger girls, suggesting that there is a sex factor concerned. This suggestion supports Childs et al. (1962) who, in their analysis of the report by Follis et al. (1952) concerning the prevalence of rickets in children up to the age of 2 dying of any cause, found a significantly greater incidence in boys than girls $(P<0.001)$.

The amounts of foods containing vitamin $\mathrm{D}$ consumed by the three races was much the same in each race and appeared adequate by usual standards, with the exception of some of the Asian girls. Of these Asian girls with serum alkaline phosphatase above $40 \mathrm{~K}$.A. units, all but one were vegetarian (often the only one in their family to adopt this diet) and all did have a deficient intake of vitamin D. It was apparent from interrogation of the schoolchildren that the habit of giving cod-liver oil or its equivalent to the older schoolchildren has stopped. The Ministry supplements of cod-liver oil for mothers and young children supplied through welfare clinics was discontinued in 1971 (to be replaced by vitamin $\mathrm{A}, \mathrm{C}$, and D drops) but the amounts given out each year had already dropped from 5.34 million bottles in 1948 to 610,000 bottles in 1970 (Office of Health Economics, 1967; Department of Health, 1971). Lumb et al. (1971) concluded from their studies that in Britain "the general state of vitamin D nutrition is probably not optimal but marginally adequate to protect against overt clinical deficiency. Such a nutritional status is peculiarly fitted to display the effects of any increase in requirement for the vitamin...." It seems likely that the dietary intake of these children in normal circumstances is only just adequate and that the physiological growth spurt brings about a relative deficiency of vitamin $\mathrm{D}$. With the ending of this spurt, the demands for vitamin $\mathrm{D}$ will be met by the normal Western diet and the disorder may thus be self limiting. Even so, the results of impaired growth or permanent pelvic deformity will not be eradicated when the disorder has become quiescent.

Since this survey shows such a high incidence of rickets, whether radiological or merely biochemical, one must question whether the sample studied was representative either in the schools themselves or of the whole school population. We believe that in the schools the children, although self selected, were representative of their respective classmates-particularly as some of the patients with rickets referred to us were also pupils at these schools. They have not, of course, been included in this survey. Clearly, other schools with different social backgrounds will need studying before figures can be obtained to calculate the true incidence of rickets in Birmingham. Nevertheless, we believe from our experience of the children with rickets referred to the unit, and who came from different schools and backgrounds, that rickets will be found in all schools to a greater or or less degree, and that the re-establishment of the custom of taking regular vitamin $\mathrm{D}$ supplements through the first decade into the teens will need to be considered.

Our thanks are due to Dr. E. D. Millar, medical officer of health, City of Birmingham; to the head teachers and their staff, for their willing help and co-operation; to Drs. R. Astley, D. K. M. Toye, and $\mathrm{P}$. Jacobs, consultant radiologists, United Birmingham Hospitals, for their independent assessment of the radiographs; to the laboratory staff of the haematological and biochemical laboratories of the General Hospital; and to Mrs. Rosemary Tudor, for the efficient organization of the equipment for the survey.

\section{References}

Belfield, A., and Goldberg, D. M. (1971). Archives of Disease in Childhood,

46, 842.
Benson, P. F., Stroud, C. E., Mitchell, N. J., and Nicolaides, A. (1963). British Medical fournal, 1, 1054.

Childs, B., Cantolino, S., and Dyke, K. K. (1962). Bulletin of the Fohns Hopkins Hospital, 110, 134.

Department of Health (1971). Health and the Health Services Since 1948. N.H.S. note 13. London, Department of Health.

Dunnigan, M. G., et al. (1962). Scottish Medical fournal, 7, 159.

Follis, R. H., Park, E. A., and Jackson, D. (1952). Bulletin of the fohn Hopkins Hospital, 91, 480.

Ford, J. A., Colhoun, E. M., McIntosh, W. B., and Dunnigan, M. G. (1972a). British Medical fournal, 2, 677.

Ford, J. A., Colhoun, E. M., McIntosh, W. B., and Dunnigan, M. G. (1972b). British Medical fournal, 3, 446.

Fourman, P., Royer, P., Levell, M. J., and Morgan, D. B. (1968). Calcium offman, R. G. (1963). Fournal of the American Medical Association, 185,

Jasin, H. E., Fink, C. W., Wise, W., and Ziff, M. (1962). Fournal of Clinical Investigation, 41, 1928.

Kind, P. R. N., and King, E. J. (1954). Fournal of Clinical Pathology, 44, 654 Loomis, W. F. (1967). Science, 157, 501.

Lumb, G. A., Mawer, E. B., and Stanbury, S. W. (1971). American Fournal of Medicine, 50, 421 .

Office of Health Economics (1967). Malnutrition in the 1960's. London, O.H.E.

Prineas, J. W., Mason, A. S., and Henson, R. A. (1965). British Medical fournal, 1, 1034.

Roberts, L. B. (1966). Clinica Chimica Acta, 16, 69.

Round, J. M. (1972). British Medical fournal, 2, 114

Sereny, G., and McLaughlin, L. (1970). Canadian Medical Association fournal, 102, 1400.

Smith, R., and Dick, M. (1968). Clinical Science, 34, 43.

Steinbach, H. L., and Kolb, F. O. (1964). American fournal of Roentgenology, Radium Therapy and Nuclear Medicine, 91, 955.

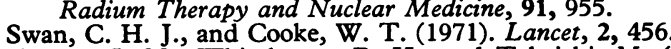

Swan, C. H. J., and Cooke, W. T. (1971). Lancet, 2, 456.
Tanner, J. M., Whitehouse, R. H., and Takaishi, M. (1966). Archives of Disease in Childhood, 41, 454 and 613 .

Thomas, P. K. (1967). Postgraduate Medical fournal, 43, 103.

Wills, M. R., Day, R. C., Phillips, T. B., and Bateman, E. C. (1972). Lancet, 1,771 .

Zorab, P. A. (1969). Lancet, 2, 1164. 